\title{
Water use and grain yield response of rainfed soybean to tillage- mulch practices in southeastern Nigeria
}

\author{
Sunday Ewele Obalum ${ }^{1 *}$, Charles Arizechukwu Igwe ${ }^{1}$, Martin Eze Obi ${ }^{1}$, Toshiyuki \\ Wakatsuki² \\ ${ }^{1}$ University of Nigeria - Dept. of Soil Science - Nsukka 410001, Nigeria. \\ ${ }^{2}$ Kinki University/School of Agriculture - Nara 631-8505, Japan. \\ *Corresponding author <ijewelle@yahoo.com> \\ Edited by: Edmilson José Ambrosano
}

\begin{abstract}
Despite the agronomic, economic and food values of soybean (Glycine max L. Merrill), there is still dearth of information on the tillage need and the implications of surface mulch for the crop in the eastern part of the forest-savanna transition zone of Nigeria. This study was therefore carried out on a sandy loam Ultisol at Nsukka with a sub-humid climate, during 2006 and 2007 cropping seasons. Our objective was to devise an appropriate tillage method for the crop from evaluated effects of no-till (NT), conventional tillage (CT) and mulch on selected key agronomic indices. Each of the NT and the CT was either unmulched (U) or mulched $(\mathrm{M})$ in a split-plot, giving four treatments/tillage methods (NTU, NTM, CTU and CTM) randomized in four blocks. Rainfall was more favorable in the first than in the second season. The mean seasonal soil water storage (range, 99-109 $\mathrm{mm}$ ) within 0.5-m soil layer differed among the treatments (NTU $<$ CTU $<$ NTM = CTM). However, for the first and second seasons, both water use (582-616 and 667-709 $\mathrm{mm}$ respectively) and grain yield (0.71-0.81 and 1.22-1.91 $\mathrm{Mg} \mathrm{ha}^{-1}$ respectively) were not different. Mulch lowered the crop water use but had no influence on grain yield. Water use efficiency was enhanced with mulch only in the second season. Although either of the two mulch treatments (NTM/CTM) would be suitable for growing soybean especially in years of unfavorably distributed rainfall, NTM is a more rational choice than CTM. Rainfall adequacy at the critical reproductive stage of the crop showed to be a more important yield factor than the tested tillage methods.
\end{abstract}

Keywords: tillage system, surface mulch, soil moisture, soybean grain yield, water use efficiency

\section{Introduction}

The cultivation of soybean (Glycine $\max$ L. Merrill) is, compared to other vegetable legumes, on the increase in Nigeria as the crop has lately been introduced to other parts from the southern Guinea Savanna region owing to its nutritive and economic values (Dugje et al., 2009; Kamara et al., 2007; Lasisi and Aluko, 2009). In various locations in the southwestern part of the forest-savanna transition zone, research-based tillage requirement of the crop has been taken care of (Ahaneku, 2006; Lasisi and Aluko, 2009; Onwualu and Ahaneku, 2001). Similar guide is yet to be reported anywhere in the southeastern part of the transition zone - including the Nsukka agroecology, which has more features of a derived savanna than any other part of the zone.

Although the current mean seasonal rainfall in the derived savanna region appears to be adequate - with respect to the water requirement - for soybean, the region is characterized by hydroclimatic fluctuations (Chukwu, 1999; Odurukwe et al., 1995) and poor soil water retention of the predominant Ultisols. These constraints often result in not meeting the water requirements of key crops and, hence, poor yields. It is necessary at this early adoption stage of the soybean crop to study its response to soil moisture induced by the routine tillage operations in this rainfed system. Agele et al. (2002) opined that such a relationship is basic to understanding adaptation and yield stability.
The no-till (NT) and the conventional tillage (CT) systems have been found to have large influence on soil moisture and crop yields (Agriculture and Rural Development, 2004). However, they are typically inconsistent in their agronomic effects, and seem to be dependent on location and crop. Specifically for soybean, the effect of tillage methods on yield is inconsistent. It has been reported to be variable among years (Norwood, 1999; Singer et al., 2008; Thiagalingam et al., 1996) or higher with NT (Pederson and Lauer, 2003; Temperly and Borges, 2006) or higher with CT (Fecak et al., 2010; Lasisi and Aluko, 2009; Onwualu and Ahaneku, 2001). There are also studies showing only marginal differences in soybean yields between NT and CT (Alvarez and Steinbach, 2009; Koga and Tsuji, 2009; Rodrigues et al., 2009). Conversely, the effect of surface mulch is almost always predictable. Surface mulch has been reported to have positive effect on the soil hydrothermal regime and crop yield (Thiagalingam et al., 1996). However, it has been hypothesized that combination of NT or CT with mulch modifies the soil surface and may have much greater impact on the soil water balance and evapotranspiration; and so would ultimately affect how efficiently crops use the rainwater input (Hatfield et al., 2001).

Since water is a primary limiting factor and, hence, an important management concern in soybean production (Deosthali et al., 2005), any chosen tillage method for the relatively new soybean crop in the Nsukka plains should 
aim at maximizing the rainwater resource for the crop. The objectives of this study were to establish the effects of NT and CT systems with and without surface mulch on the soil moisture status, water use (WU), grain yield and water use efficiency (WUE) of soybean grown in a sandy loam soil under rainfed condition at Nsukka, southeastern Nigeria.

\section{Materials and Methods}

The experiment was carried out at Nsukka (06 $52^{\prime} \mathrm{N}$, $07^{\circ} 24^{\prime}$ E, $400 \mathrm{~m}$ a.s.l.) in southeastern Nigeria. Generally, the climate is characterized by mean annual total rainfall of about 1,600 mm. The entire wet season lasts from April to October, with a short break in-between two phases as the rainfall is bimodally distributed; whereas the dry season lasts from November to March. On the average, the potential evapotranspiration (PET) normally exceeds rainfall in a year. The rainfall-PET dynamics as well as the prevailing air temperature during the months of the growing seasons is depicted in Figure 1.

The soil belongs to the Nkpologu series and was classified as a Typic Paleustult. It is essentially a mineral soil that is deep and well-drained, with an ustic soil moisture regime and an isohyperthermic soil thermal regime. Runoff rarely occurs on the experimental site not only because of its gentle slope (only about 1-2\%), but also due to high infiltration rate encouraged by its coarse texture and unfavorable aggregation. Steady state infiltration rate ranges from 240 to 750 $\mathrm{mm} \mathrm{h}^{-1}$ (Obi and Nnabude, 1988). The initial characterization of the soil based on selected physicochemical properties is shown in Table 1.

Being in the forest-savanna transition vegetation zone, grasses dominate the natural vegetation, with few interspersing leguminous weeds. Some of the grass species identified at the site included Andropogon gayanus, Celosia trigyna,

Table 1 - Some physicochemical properties of the top$0.1 \mathrm{~m}$ soil at the start of the study.

\begin{tabular}{|c|c|c|c|}
\hline \multicolumn{4}{|c|}{ Soil Properties } \\
\hline \multicolumn{2}{|l|}{ Physical } & \multicolumn{2}{|l|}{ Chemical } \\
\hline Sand $\left(\mathrm{g} \mathrm{kg}^{-1}\right)$ & 752 & $\mathrm{pH}$ in $\mathrm{H}_{2} \mathrm{O}$ & 6.6 \\
\hline Silt $\left(\mathrm{g} \mathrm{kg}^{-1}\right)$ & 160 & $\mathrm{SOM}\left(\mathrm{g} \mathrm{kg}^{-1}\right)$ & 8.6 \\
\hline Clay $\left(\mathrm{g} \mathrm{kg}^{-1}\right)$ & 88 & Total N $\left(\mathrm{g} \mathrm{kg}^{-1}\right)$ & 1.1 \\
\hline Bulk density $\left(\mathrm{Mg} \mathrm{m}^{-3}\right)$ & 1.46 & Available P (mg kg-1) & 28 \\
\hline Total porosity & 0.57 & $\mathrm{CEC}\left(\mathrm{mmol}_{\mathrm{c}} \mathrm{kg}^{-1}\right)$ & 70 \\
\hline Macroporosity & 0.12 & $\begin{array}{l}\text { Exchangeable bases } \\
\left(\mathrm{mmol}_{\mathrm{c}} \mathrm{kg}^{-1}\right)\end{array}$ & 34 \\
\hline Microporosity & 0.45 & $\mathrm{Ca}\left(\mathrm{mmol}_{\mathrm{c}} \mathrm{kg}^{-1}\right)$ & 17 \\
\hline MWD (mm) & 2.3 & $\operatorname{Mg}\left(\mathrm{mmol}_{\mathrm{c}} \mathrm{kg}^{-1}\right)$ & 12 \\
\hline $\mathrm{K}_{\text {sat }}\left(\mathrm{cm} \mathrm{h}^{-1}\right)$ & 8.3 & $\mathrm{Na}\left(\mathrm{mmol}_{\mathrm{c}} \mathrm{kg}^{-1}\right)$ & 4 \\
\hline *AWC (mm 0.5-m-1) & 90 & $\mathrm{~K}\left(\mathrm{mmol}_{\mathrm{c}} \mathrm{kg}^{-1}\right)$ & 1 \\
\hline
\end{tabular}

$\mathrm{K}_{\text {sat }}$ - saturated hydraulic conductivity; MWD - mean weight diameter. AWC - available water capacity *(moisture held between 0.06- and 15-bar tension). SOM - soil organic matter. CEC cation exchange capacity
Emilia sonchifolia, Pennisetum polystachion, and Spermacoce verticillata. Leguminous weeds were represented by Calapagonium mucunoides and Mucuna urens; broad leaf weeds by Asystasia gangetica. In 2006 when the study was initiated, the field had been under a mixed-species fallow for about ten years.

Land clearing was manually achieved at the site with minimal soil disturbance at the beginning of each cropping season in both years (2006 and 2007) of the study. Prior to the pre-planting tillage operations in each year, thoroughly mixed organic manure (poultry droppings) was uniformly applied in the entire field at a rate of $5 \mathrm{Mg} \mathrm{ha}^{-1}$; no inorganic fertilizers were used. This was based on the recommended rate of poultry manure that would serve as a substitute for inorganic fertilizer for soybean (Kratochvil et al., 2006). Treatments consisted of a factorial set-up with NT and CT as the main plots, and unmulched and mulched conditions as the sub-plots. This $2 \times 2$ split-plot arrangement yielded four treatments: NT, unmulched (NTU); NT, mulched (NTM); CT, unmulched (CTU); and CT, mulched (CTM). The NT plots were just clean-weeded flat beds; the CT plots were seedbeds manually prepared by ploughing to the depth of about $0.2 \mathrm{~m}$. Treatments were replicated four times in a randomized complete block design (RCBD). In the NT plots, the only soil disturbance occurred during seeding and occasional weeding, both operations of which were carried out with caution. The subplot size was 4.2 $\mathrm{m} \times 2.1 \mathrm{~m}$. Raised earthen bunds with separating pathways (width, $0.4 \mathrm{~m}$ ) were used to demarcate the blocks. The entire field, measuring $18 \mathrm{~m} \times 8.4 \mathrm{~m}$, was fenced round using earthen bunds.

In line with the recommended agronomic practices for soybean (Dugje et al., 2009; ICS-Nigeria, 2003), an early-maturing cultivar (SAMSOY-2) was treated with Apron Star and manually sown at three per hill in 2-4 cm depth on 3 July, 2006 and 7 June, 2007. Crop stands were spaced $0.6 \mathrm{~m}$ between and $0.3 \mathrm{~m}$ within rows, resulting a population of 55,555 plants per hectare. Seedlings

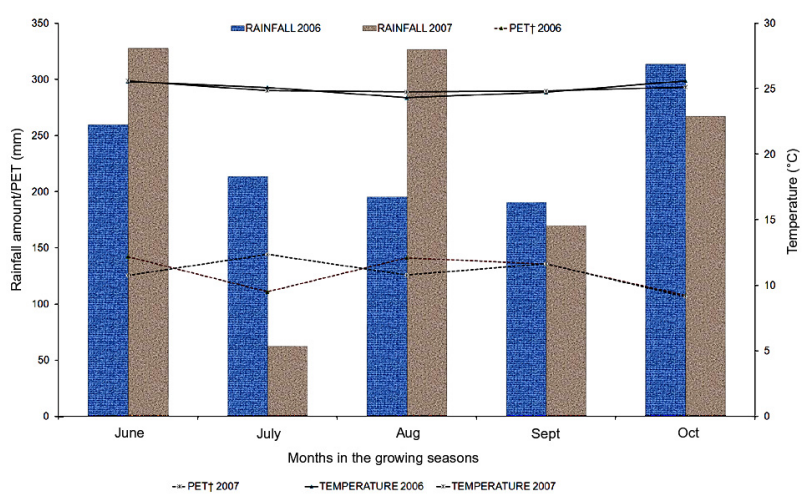

Figure 1 - Some climatic variables for the months in the 2006 and 2007 growing seasons †Potential evapotranspiration, calculation of which was based on Blaney-Criddle equation (Blaney and Criddle, 1950). 
were later thinned down to one per stand 14 days after sowing (DAS). Application of mulch followed immediately after thinning. The mulch material was composed mainly of dry leaves of Paspalum notatum, and was applied at the rate of $5 \mathrm{Mg} \mathrm{ha}^{-1}$. All plots were kept free from weeds using a hand hoe or by hand picking throughout the study; no herbicides were used.

The three components of water balance needed for the computation of crop WU were precipitation $(\mathrm{P})$, drainage (D) below the root zone, and change in storage $(\Delta S)$ during the growing season. The daily values of $P$ for the entire period were obtained from the University Meteorological Station, located about $50 \mathrm{~m}$ away from the study site. To obtain $\Delta S$, the soil was sampled immediately after sowing, on the assumption that the profile had been wetted homogenously. Subsequent soil sampling for determination of the profile soil water storage was started two weeks after mulch application and continued at $10 \pm 1$-day intervals until harvest. This sampling interval was based on the postulation that plant water need over periods of about ten days would usually be met by soil water storage (Stern et al., 1982). Sampling was limited to the $0.5 \mathrm{~m}$ depth zone, the zone of greatest root density of soybean (FAO, 2002; Willatt and Olsson, 1982).

On each sampling occasion, the approach used by Hulugalle and Lal (1986), Moitra et al. (1996) and Zougmore et al. (2004) in determining the storage in a $0.5 \mathrm{~m}$ layer in similar studies with soils of the same textural class (sandy loam) as the present soil, was adopted. This involved the use of a graduated tube auger to sample down to the $0.5 \mathrm{~m}$ depth in a single swoop and partitioning the soil sample into top- $(0-0.3 \mathrm{~m})$ soil and sub-(0.3-0.5 m) soil, before determining their water contents gravimetrically. Using pre-determined mean soil bulk densities, the gravimetric water contents were converted to volumetric basis. The volumetric water content was multiplied by the thicknesses of the respective soil layers (in $\mathrm{mm}$ ) to express on depth basis. The values from the two soil layers were summed up to obtain the root zone moisture storage (in $\mathrm{mm}$ ).

During the sampling period, two of the four replicates of each treatment were selected for monitoring the soil water storage $S$. Designated portions, centrally located within the plots and away from the border rows, were permanently marked for the repeated water content measurements. To maximize the chances of sampling on days when differences did appear, the principle of not monitoring immediately after rains was adopted, hence the \pm 1 -day allowance in the sampling intervals. With this principle, the aim was not to achieve an exact picture of the crop's daily WU during the growing season, but to identify differences among treatments (Tilander and Bonzi, 1997). The experimental field was sampled nine and eight times before harvest in the first and second years, respectively. The $\Delta S$ was calculated as the difference between the total value of water storage on all the sampling dates and the corresponding value on all respective preceding dates.

$D$ was simulated as outflow from a nearby (about $30 \mathrm{~m}$ away) well-designed non-weighing drum lysimeter, buried at the soil surface level over 25 years ago. The outflow was mea- sured on daily basis. Based on the assumption that the drainage process of deep percolation took place only when the theoretical field capacity (simulated at 0.6-m-water tension) was exceeded (Oluwasemire et al., 2002), water storage and $D$ under the treatments were regarded as variables that exhibited an inverse relationship. Thus, the values of water storage were used to adjust $D$ for the different treatments.

A simple water balance equation was used to compute crop WU or evapotranspiration (ET): ET $=\mathrm{P}-\mathrm{D}-\Delta \mathrm{S}$.

In order to examine the effect of water deficit conditions on grain yield during the growing seasons, an analysis of water stress at different growth stages was carried out using the Moisture Availabilty Index (MAI), the ratio of available water to PET (Srivastava et al., 1996). PET was calculated using the Blaney-Criddle Model (Blaney and Criddle, 1950). A MAI value of $100 \%$ implies that the dependable rainfall equals PET. The intensity of water stress for soybean was determined after Srivastava et al. (1996), as the lowest required MAI values at various stages of development of the crop; $75 \%$ during the seedling stage, $100 \%$ during the vegetative/reproductive stage, and $50 \%$ during the maturity stage.

Soybean pods were harvested at maturity and this took place on 27 October, 2006 (116 DAS in the first year) and 24 October, 2007 (138 DAS in the second year). Grain yield was assessed using 16 plants (consisting of four $\times$ four rows of plants) from the designated central portion in each sub-plot. Dry pods were threshed to separate the seeds from the chaff, and weights of the seeds (grain yield) taken thereafter. The Yield-WU relationship was assessed by WUE, expressed as the measured grain yield $(\mathrm{kg})$ per land area (ha) per water consumptive use ( $\mathrm{mm})$.

Analysis of variance (ANOVA) procedure for a split-plot in RCBD was used to test the data under the treatments for differences. The separation of treatment means (for statistical comparison) was achieved by the procedure of Fisher's least significant difference (F-LSD) as described by Obi (2002).

\section{Results and Discussion}

The pattern of rainfall in the two growing seasons (Figure 1) clearly depicts the exact nature of the hydroclimatic variability that characterizes the study area. By the traditional features, rainfall is bimodally distributed and reaches its peak in the months of July and October in the longer and shorter sub-wet seasons respectively. This was observed in 2006. A point of deviation in 2007 worth mentioning was that the peak in the longer sub-wet season, instead of occurring in July, occurred in August - when ordinarily a period of short break with the least rainfall would be expected. On the other hand, analyses of the daily rainfall showed that drizzles (individual rain events $<10 \mathrm{~mm}$ in depth) occurred 55 and 45 times, amounting to 236 and $182 \mathrm{~mm}$ respectively, in the first and second seasons respectively. For rainstorms (individual rain events $\geq 40 \mathrm{~mm}$ ), the corresponding values were two and six times and 92 and $267 \mathrm{~mm}$. Rainfall distribution was, therefore, more favorable in 2006 compared with 2007. 


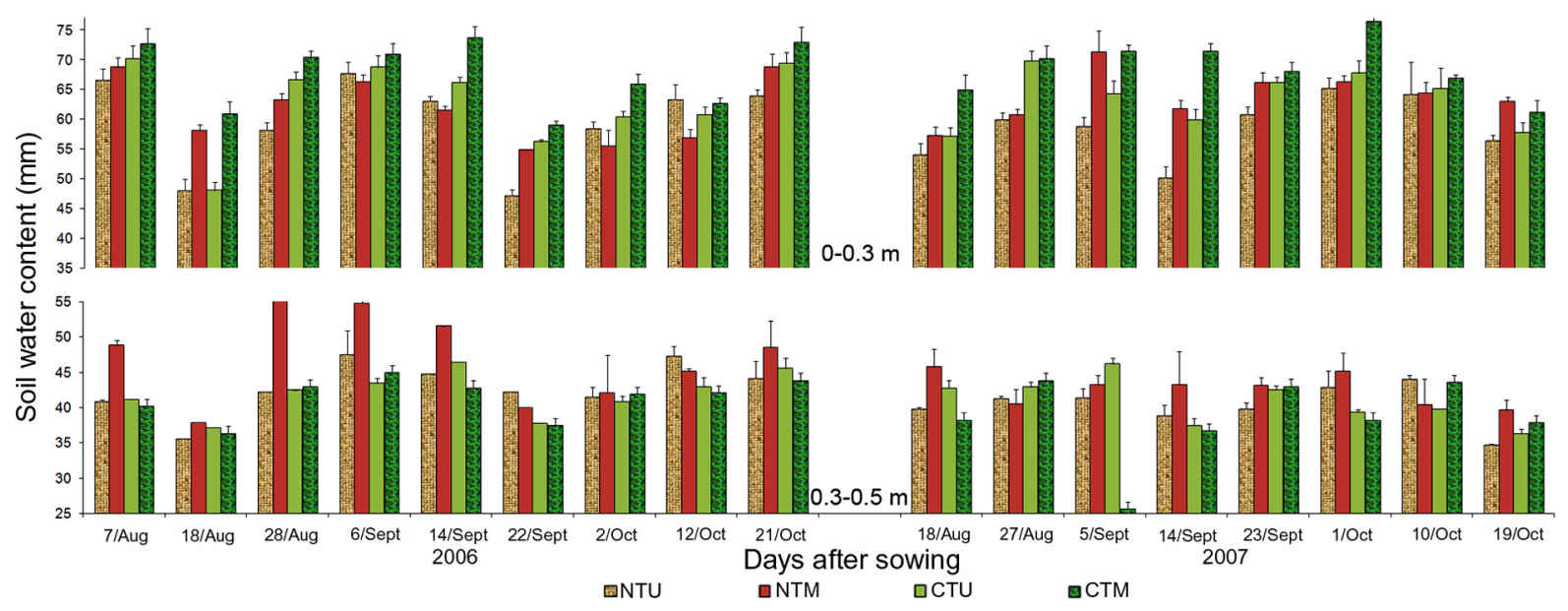

Figure 2 - Water contents of the 0-0.3 and 0.3-0.5 m layers under the treatments across the sampling dates NTU - No-till, unmulched; NTM - No-till, mulched; CTU - Conventional tillage, unmulched; CTM - Conventional tillage, mulched. Error bars are standard deviations of the measurements for each treatment.

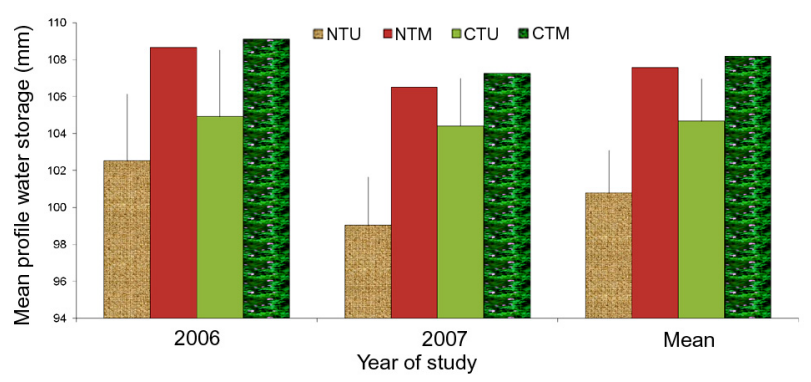

Figure 3 - Mean soil water storage in the $0.5-\mathrm{m}$ profile across the sampling dates in both years of the study. NTU - No-till, unmulched. NTM - No-till, mulched. CTU - Conventional tillage, unmulched. CTM Conventional tillage, mulched. The vertical error bars represent the $\operatorname{LSD}_{(0.05)}$ among the treatments.

Overall, the CTM and the NTM appeared to have the most influence on soil water in the $0-0.3$ and $0.3-0.5 \mathrm{~m}$ layers respectively (Figure 2). Apart from reflecting the depth of tillage, this trend also buttresses the importance of mulch in soil water conservation. The mean seasonal values of $\mathrm{S}$ in the entire monitored profile differed $(p<0.05)$ among the tillage methods (Figure 3). Averaged over the two years, the soil water status decreased from the two mulch treatments (NTM and CTM) through the CTU to the NTU.

Higher $S$ under the mulched compared to the unmulched treatments was evident in especially the top- $(0.3$ $\mathrm{m}$ ) soil layer during the early phase of the growing season, when deterioration of the organic mulch material had not set in (Figure 2). The better soil water condition of the mulched plots relative to the unmulched plots was, therefore, due to the water conserved under mulch during the early growth phase. Rathore et al. (1998) reported similar results with straw mulch in the profile of a chickpea field. Moreover, the overall soil water relation was more favorable under the mulched than the unmulched plots, as indicated by the moderate and lower saturated hydraulic con- ductivity in the former compared to the rapid and higher values in the latter, at the end of the study (Obalum and Obi, 2010). On the other hand, the better soil moisture status under the CTU relative to the NTU was attributed to the enhanced rainwater infiltration into the former due to the presence of large clods and larger surface area (Ali and Talukder, 2008; Hatfield et al., 2001). The fact that this prevailed only in the unmulched treatments is indicative of the overriding influence of the mulch on the effects of NT and CT on soil moisture.

In both growing seasons, the tillage systems had no influence on the total WU of the crop (Table 2). There was a reduction $(p \leq 0.05)$ in the total WU due to the applied mulch in the two years of the study. Higher evaporation from the surface and topmost part of the soil may have taken place under the unmulched treatments especially early in the season. This was probably not compensated for by an increase in transpiration following better vegetative growth under mulch at a later stage, hence the differences in the total WU. Similar to these results, the WU of chickpea grown under tillage-mulch treatments did not differ between the NT and the CT, but was lower under mulch compared to unmulched plots (Rathore et al., 1998). In the present study, the WU values indicated higher water consumptive use in the second than in the first season. Considering the dependency of the water requirement of the soybean crop on length of growing season (FAO, 2002), higher WU would be expected in the second season, in which the crop remained 22 days more in the field, compared to the first season.

Treatments had no effects on the grain yield in either of the two years (Table 3). Soybean is non-responsive to tillage systems (Alvarez and Steinbach, 2009; Koga and Tsuji, 2009; Kramer and Alberts, 1988; Rodrigues et al., 2009; Wilhelm and Wortmann, 2004; Yusuf et al., 1999). Kramer and Alberts (1988) concluded, after a six-year study, that tillage systems had no effect on grain yield of soybean. Soybean in NT exhibited compensatory reproductive growth to the early season plant development 
Table 2 - Total water use of the soybean crop as computed from the components of the water balance in the two years of the study.

\begin{tabular}{|c|c|c|c|c|c|c|c|c|c|c|c|c|}
\hline \multirow{3}{*}{ Treatment } & \multicolumn{3}{|c|}{ Final storage $\left(\mathrm{S}_{\mathrm{f}}\right)$} & \multicolumn{3}{|c|}{ Initial storage $\left(\mathrm{S}_{\mathrm{i}}\right)$} & \multicolumn{3}{|c|}{ Drainage (D) } & \multicolumn{3}{|c|}{ Total water use or $\mathrm{ET}_{\text {crop }}$} \\
\hline & \multicolumn{12}{|c|}{ - } \\
\hline & UM & M & Mean & UM & M & Mean & UM & M & Mean & UM & M & Mean \\
\hline & & & & & & & $200 c$ & & & & & \\
\hline NT & 923 & 978 & 951 & 920 & 931 & 926 & 219 & 206 & 213 & 614 & 582 & 598 \\
\hline CT & 945 & 982 & 964 & 938 & 941 & 940 & 213 & 208 & 211 & 616 & 587 & 602 \\
\hline \multirow[t]{2}{*}{ Mean } & 934 & 980 & & 929 & 936 & & 216 & 207 & & 615 & 585 & - \\
\hline & \multicolumn{12}{|c|}{$\operatorname{HLSD}_{(0.05)}$} \\
\hline & \multicolumn{12}{|c|}{2007} \\
\hline NT & 793 & 852 & 822 & 811 & 834 & 823 & 243 & 223 & 233 & 698 & 681 & 690 \\
\hline CT & 835 & 858 & 847 & 851 & 828 & 840 & 229 & 225 & 227 & 709 & 667 & 688 \\
\hline \multirow[t]{3}{*}{ Mean } & 814 & 855 & & 831 & 831 & & 236 & 224 & & 703 & 674 & - \\
\hline & \multicolumn{12}{|c|}{$\dagger \operatorname{LSD}_{(0.05)}$} \\
\hline & \multicolumn{12}{|c|}{ Mean } \\
\hline NT & 858 & 915 & 887 & 866 & 883 & 875 & 231 & 215 & 223 & 656 & 632 & 644 \\
\hline CT & 890 & 920 & 905 & 895 & 885 & 890 & 221 & 217 & 219 & 663 & 627 & 645 \\
\hline \multirow[t]{2}{*}{ Mean } & 874 & 918 & & 880 & 884 & & 226 & 216 & & 659 & 629 & - \\
\hline & & & & & & & & & $\dagger \operatorname{LSD}_{(0.05)}$ & $\mathrm{ns}, 27.5^{*}, \mathrm{~ns}$ & & \\
\hline
\end{tabular}

The field received 836 and $923 \mathrm{~mm}$ of precipitation $(\mathrm{P})$ between sowing and harvest in 2006 and 2007 respectively. $\mathrm{S}_{\mathrm{f}}$ and $\mathrm{S}_{\mathrm{i}}$ represent the total values on all the sampling dates from sowing to harvest; $\mathrm{S}_{\mathrm{f}}-\mathrm{S}_{\mathrm{i}}=\Delta \mathrm{S}$. P $-\Delta \mathrm{S}-\mathrm{D}=\mathrm{ET}$ (crop evapotranspiration). NT $-\mathrm{No}$-till; CT - Conventional tillage; UM - Unmulched; M - Mulched. †Given for tillage system, mulch practice, and tillage $\mathrm{x}$ mulch in that order; ns stands for not significant at the chosen level of probability.

Table 3 - Grain yield and water use efficiency of soybean.

\begin{tabular}{|c|c|c|c|c|c|c|}
\hline \multirow{3}{*}{ Treatment } & \multicolumn{3}{|c|}{ Grain yield } & \multicolumn{3}{|c|}{ Water use efficiency } \\
\hline & \multicolumn{3}{|c|}{ - } & \multicolumn{3}{|c|}{ - $\mathrm{kg} \mathrm{ha}^{-1} \mathrm{~mm}^{-1}$} \\
\hline & UM & M & Mean & $\mathrm{UM}$ & $\mathrm{M}$ & Mean \\
\hline & \multicolumn{6}{|c|}{2006} \\
\hline NT & 0.71 & 0.81 & 0.76 & 1.16 & 1.40 & 1.28 \\
\hline $\mathrm{CT}$ & 0.71 & 0.81 & 0.76 & 1.16 & 1.38 & 1.27 \\
\hline \multirow{3}{*}{$\begin{array}{l}\text { Mean } \\
+\mathrm{LSD}_{(0.05)}\end{array}$} & 0.71 & 0.81 & - & 1.16 & 1.39 & - \\
\hline & \multicolumn{6}{|l|}{$\mathrm{ns}, \mathrm{ns}$, ns } \\
\hline & \multicolumn{6}{|c|}{2007} \\
\hline NT & 1.54 & 1.91 & 1.72 & 2.20 & 2.80 & 2.50 \\
\hline CT & 1.22 & 1.73 & 1.48 & 1.73 & 2.59 & 2.16 \\
\hline Mean & 1.38 & 1.82 & - & 1.96 & 2.70 & - \\
\hline \multirow[t]{2}{*}{$+\operatorname{LSD}_{(0.05)}$} & $\mathrm{ns}, \mathrm{ns}, \mathrm{ns}$ & & & $\mathrm{ns}, 0.69^{*}$ & & \\
\hline & \multicolumn{6}{|c|}{ Mean } \\
\hline NT & 1.13 & 1.36 & 1.24 & 1.68 & 2.10 & 1.89 \\
\hline $\mathrm{CT}$ & 0.97 & 1.27 & 1.12 & 1.45 & 1.99 & 1.72 \\
\hline \multirow{2}{*}{$\begin{array}{r}\text { Mean } \\
+\mathrm{LSD}_{(0.05)}\end{array}$} & 1.05 & 1.32 & - & 1.56 & 2.05 & \\
\hline & $\mathrm{ns}, \mathrm{ns}, \mathrm{ns}$ & & \multicolumn{4}{|c|}{$\mathrm{ns}, 0.48^{*}$, ns } \\
\hline
\end{tabular}

NT - No-till; CT - Conventional tillage; UM - Unmulched; M - Mulched. †Given for tillage system, mulch practice, and tillage $\times$ mulch in that order. ns stands for not significant at the chosen level of probability.

in CT, thereby minimizing yield differences between the two tillage systems (Yusuf et al., 1999). Growth attributes such as plant height and number of leaves mea- sured at three stages followed a similar trend as grain yield, i.e., comparable values among the treatments (data not shown). 
Although the tillage-induced differences in grain yields were not appreciable, NT out-yielded CT by $16.2 \%$ in the second year which was implicated with the unfavorable rainfall pattern. Singer et al. (2008), who reported inconsistent results over a three-year period, equally observed that years with unfavorable rainfall favored NT. The result of the present study differs from the higher yield with CT reported for soybean by Lasisi and Aluko (2009) in southwestern Nigeria, the similarity in the soil textural attribute of the present location to theirs notwithstanding. The disparity is attributed partly to the fact that, unlike the manual CT in this study which rarely exceeded the top $0.2 \mathrm{~m}$, Lasisi and Aluko (2009) used tractor-mounted implements to achieve deeper and more intensive ploughing and harrowing. The disparity could have also resulted partly from the differences in local soil and climatic conditions.

In spite of the higher mean seasonal water storage observed under the mulched (NTM and CTM) compared to the unmulched (CTU and NTU) treatments (Figure 3), the grain yields were only marginally higher in the former than the latter (Table 3). This weak cause-effect relationship between soil moisture and grain yield was further highlighted in the contrasting trends of the two parameters under the NTU and the CTU in the second season and in the seasonweighted means. The inconsistent effects of the tillage systems on water contents of the topsoil layers (data not shown), was presumably the reason why the effect of tillage methods on soil moisture could not reflect on crop yield. Hakansson and von Polgar (1984) observed similar situation and showed how such differences could eliminate variations in yield responses on seedbeds. Some other authors equally indicated that changes in soil water content in response to tillage were not of the magnitude to influence crop yield (Aboudrare et al., 2006; Anikwe and Ubochi, 2007; Tessier et al., 1990).

Rather than the soil moisture status, the effects on other key soil properties would help to explain the yield results. Organic matter content of the soil has, among a range of soil properties including $\mathrm{P}$ and $\mathrm{K}$ concentrations, been shown to have the greatest influence on grain yield of soybean (Kravchenko and Bullock, 2000). At the end of the present study, organic matter contents - as well as the structural properties - of the soil maintained same values under the various treatments (Obalum and Obi, 2010). Similarly, available P was the only fertility parameter that differed $(p \leq 0.05)$ under the unmulched plots (18.6 $\mathrm{mg} \mathrm{kg}^{-1}$ soil) and their mulched counterparts $(21.9 \mathrm{mg}$ $\mathrm{kg}^{-1}$ soil). Soybean is a high $\mathrm{P}$-dependent crop in the savanna region of Nigeria (Chiezey and Odunze, 2009; Kamara et al., 2007; Mahamood et al., 2009). So, the more favorable P status of the mulched than the unmulched treatments may likely be the reason for the numerically higher yields under the former than the latter.

Variations in yields of the crop were more between the two years of the study than among the treatments. The grain yields were higher $(p \leq 0.001)$ in 2007 relative to 2006 (Table 3), in spite of the water deficit condition that prevailed in 2007 during July - when PET was appreciably below rainfall (Figure 1). This was probably because the water deficit between 36 and 54 DAS, took place during the R2 (full bloom) stage, when crop water demand was lowest. Soil water deficit during this stage has similarly been reported not to cause grain yield decline of soybean (Deosthali et al., 2005; Foroud et al., 1993; Karam et al., 2005). Moreover, the analysis of water stress based on MAI during the growing season (Figure 4) shows that the values were consistently above the $75 \%$ threshold for that stage (Srivastava et al., 1996). The MAI data reveal instead that the crop actually experienced more yield-relevant water stress in 2006 compared with 2007. A perusal of the figure would show that the MAI was lower than $100 \%$ during the R3-R4 (pod development) stage (46-80 DAS) in 2006. This corresponded to the period of normal short break in rainfall. Such a situation has been found to cause appreciable yield decline (Srivastava et al., 1996). Conversely, there was no such scenario during this critical reproductive stage and the maturity stages in the 2007 growing season.

Although soybean yield is relatively insensitive to shortage of water during the vegetative growth, WU must not be less than the potential demand during the pod-filling stage (Agele et al., 2004; FAO, 2002; Fecak et al., 2010; Foroud et al., 1993; Rasiah and Kohl, 1991). The view that a high MAI $(>160 \%$ ) would result in soybean yield reduction did not apply in the present study because the soil was moderately well-drained with fairly good aeration and therefore supports a good soybean growth under high MAI conditions (Deosthali et al., 2005). Moreover, the high MAI was shortlived. The present results suggest that, unless the drought and associated water stress to soybean does not coincide with the critical stage of development when ET is supposed to be at optimum rate, the seasonal rainfall pattern may have

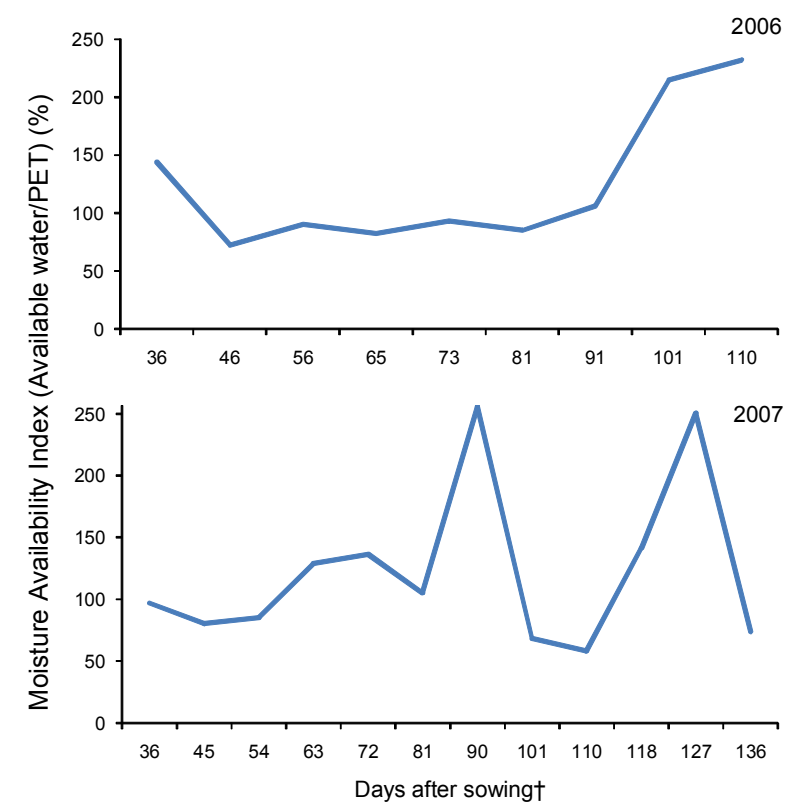

Figure 4 - Water stress index of the soybean crop during 2006 and 2007 growing seasons. fcounted as from 3 July in 2006 and 7 June in 2007. 
strong influence on grain yield of the crop. Fecak et al. (2010) also reported, following a similar study, that climatic condition was the most dominant factor that influenced the grain yield of soybean in Milhostov, Slovak Republic.

Such other factors as cropping history may also be partially implicated for the relatively poor yield in the first season. Soybean performs poorly in the first year of establishment on a plot not cropped to it for some three years, due to the absence of residual effect of nodulation (Kratochvil et al., 2006). Another possible factor is that the soil $\mathrm{pH}$ dropped from 6.6 before cropping in the first year (Table 1) to 5.3 after the study. These $\mathrm{pH}$ values suggest a more favorable soil reaction for the crop in the second than in the first season, since the desirable $\mathrm{pH}$ for optimum soybean yield has been shown to be in the range of 5-6 (FAO, 2002; Kratochvil et al., 2006).

As with the WU, there were no tillage-induced differences in WUE in both growing seasons (Table 3). In the first season, mulch did not result in significantly higher WUE, despite the lower seasonal WU under the mulch plots. This observation suggests that the higher soil moisture status under mulch in such a good rainfall season was not due to the evaporation-reducing attribute of the mulch, neither was the lower WU with mulch due to a more beneficial consumptive use of soil water under mulch. Instead, these benefits associated with mulch in the first season were conceivably due to better encouragement of infiltration of the trapped and transiently restrained rainwater by the mulch material (Adekalu et al., 2007). In contrast, mulch $(p \leq 0.05)$ enhanced WUE in the second year that was characterized by erratic rainfall during the growing season. Similar enhancement of WUE under mulch compared to unmulched plots was reported for chickpea in a semi-arid environment (Rathore et al., 1998). In the present study, the range of WUE values for the soybean crop in the second season (when the yield was higher) was 1.81-2.87 kg $\mathrm{ha}^{-1} \mathrm{~mm}^{-1}$. This compares favorably with the range $(2.00-$ $2.35 \mathrm{~kg} \mathrm{ha}^{-1} \mathrm{~mm}^{-1}$ ) reported for the crop under similar management and dryland conditions elsewhere (Norwood, 1999; Varvel, 1995).

\section{Conclusions}

The NT and the CT for the growing of soybean in this sandy loam Ultisol produced comparable agronomic effects, evident in the soil moisture status, consumptive use of water and grain yield of the crop. Although mulch enhanced the soil moisture status and lowered the crop WU, it had no influence on grain yield. Hence, NTM and CTM conserved soil water better than NTU and CTU, but there were no differences in WU, grain yield and WUE among these four tillage methods. Surface mulch proved to be useful for enhancing soybean WUE especially in a bad rainfall season. Besides, the mulch treatments (NTM and CTM) have the potential benefit of bequeathing the soil water conserved under them to the succeeding crop. Considering the relative requirements of the two tillage methods, it would be preferable to grow soybean with no-till under mulch (NTM) condition.

\section{Acknowledgements}

This study is a partial fulfillment of the requirements of a Master of Science Degree of the senior author by the University of Nigeria.

\section{References}

Aboudrare, A.; Debaeke, P.; Bouaziz, A.; Chekli, H. 2006. Effects of soil tillage and fallow management on soil water storage and sunflower production in a semi-arid Mediterranean climate. Agricultural Water Management 83: 183-196.

Adekalu, K.O.; Olorunfemi, I.A.; Osunbitan, J.A. 2007. Grass mulching effect on infiltration, surface runoff and soil loss of three agricultural soils in Nigeria. Bioresource Technology 98: 912-917.

Agele, S.O.; Adenawoola, A.R.; Doherty, M. 2004. Growth response of soybean lines to contrasting photothermal and soil moisture regimes in a Nigerian tropical rainforest. International Journal of Biotronics 33: 49-64.

Agele, S.O.; Olufayo, A.; Iremiren, G.O. 2002. Effects of season of sowing on water use and yield of tomato in the humid south of Nigeria. African Crop Science Journal 10: 231-237.

Agriculture and Rural Development. 2004. Tillage effects on soil moisture. Available at: http://www1.agric.gov.ab.ca/\$department/ deptdocs.nsf/all/eng8174/\$file/

/Tillage_Effects_on_Soil_Moisture.pdf?OpenElement. [Accessed June 14, 2006].

Ahaneku, I.E. 2006. Influence of tillage method on emergence and yield of soybean. Discovery and Innovation 18: 30-36.

Ali, M.H.; Talukder, M.S.U. 2008. Increasing water productivity in crop production - A synthesis. Agricultural Water Management 95: 1201-1213.

Alvarez, R.; Steinbach, H.S. 2009. A review of the effects of tillage systems on some soil physical properties, water content, nitrate availability and crops yield in the Argentine Pampas. Soil and Tillage Research 104: 1-15.

Anikwe, M.A.N.; Ubochi, J.N. 2007. Short-term changes in soil properties under tillage systems and their effect on sweet potato (Ipomea batatas L.) growth and yield in an Ultisol in southeastern Nigeria. Australian Journal of Soil Research 45: 351-358.

Blaney, H.F.; Criddle, W.D. 1950. Determining water requirement in irrigated areas from climatological data..USDA-NRCS. Washington DC, USA. (USDA/NRCS Technical Paper, 96).

Chiezey, U.F.; Odunze, A.C. 2009. Soybean response to application of poultry manure and phosphorus fertilizer in the Sub-humid Savanna of Nigeria. Journal of Ecology and Natural Environment 1: 25-31.

Chukwu, G.O. 1999. Estimation of water requirements of soybean and groundnut in Southeastern Nigeria. Journal of Sustainable Agriculture and Environment 1: 150-154.

Deosthali, V.; Akmanchi, A.; Salunke, C. 2005. Soybean agriculture in India: a spatial analysis. Transactions of the Institute of Indian Geographers 27: 13-31.

Dugje, I.Y.; Omoigui, L.O.; Ekeleme, F.; Bandyopadhyay, R.; Lava Kumar, P.; Kamara, A.Y. 2009. Farmers' guide to soybean production in Northern Nigeria. International Institute of Tropical Agriculture, Ibadan, Nigeria. Available at: http://www.icrisat.org/ tropicallegumesII/pdfs/Soybean.pdf [Accessed Sep. 22, 2009].

Fecak, O.; Sarikova, D.; Cerny, I. 2010. Influence of tillage system and starting $\mathrm{N}$ fertilization on seed yield and quality of soybean Glycine $\max ($ L.) Merrill. Plant, Soil and Environment 56: 105-110.

Food and Agriculture Organization [FAO]. 2002. Crop water management: soybean. agriculture, land, and water. AGLW, Rome, Italy. Available at: www.fao.org/landandwater/aglw/ cropwater/soybean.stm. [Accessed June 18, 2006].

Foroud, N.; Mundel, H.H.; Saindon, G.; Entz, T. 1993. Effect of level and timing of moisture stress on soybean yield components. Irrigation Science 13: 149-155. 
Hakansson, I.; von Polgar, J. 1984. Experiments on the effects of seedbed characteristics on seedling emergence in a dry weather situation. Soil and Tillage Research 4: 115-135.

Hatfield, J.L.; Sauer, T.J.; Prueger, J.T. 2001. Managing soils to achieve greater water use efficiency: a review. Agronomy Journal 93: 271-280.

Hulugalle, N.R.; Lal, R. 1986. Soil water balance of intercropped maize and cowpea grown in a tropical hydromorphic soil in Western Nigeria. Agronomy Journal 78: 86-90.

ICS-Nigeria 2003. Growing soybean in Nigeria USAID/ICS Available at: http://www.ics-nigeria.info/publications_1.htm. [Accessed Mar. 11, 2007]. (Commercial Crop Production Guide Series).

Kamara, A.Y.; Abaidoo, R.; Kwari, J.; Omoigui, L. 2007. Influence of phosphorus application on growth and yield of soybean genotypes in the tropical savannas of northeast Nigeria. Archives of Agronomy and Soil Science 53: 539-552.

Karam, F.; Masaad, R.; Sfeir, T.; Mounzer, O.; Rouphael, Y. (2005). Evapotranspiration and seed yield of field grown soybean under deficit irrigation conditions. Agricultural Water Management 75: 226-244.

Koga, N.; Tsuji, H. 2009. Effects of reduced tillage, crop residue management and manure application practices on crop yields and soil carbon sequestration on an Andisol in northern Japan. Soil Science and Plant Nutrition 55: 546-557.

Kramer, L.A.; Alberts, E.E. 1988. Effect of three tillage systems on corn and soybean growth and grain yield. ASAE Paper No., MCR-88-111. American Society of Agricultural Engineers, St. Joseph, MI, USA.

Kratochvil, R.J.; Pearce, J.T.; Harrison, M.R. 2006. Spacing and seeding for glyphosate-resistant soybean. CCA/AGP. Available at: www.agprofessional.com. [Accessed June 18, 2006].

Kravchenko, A.N.; Bullock, D.G. 2000. Correlation of corn and soybean grain yield with topography and soil properties. Agronomy Journal 92: 75-83.

Lasisi, D.; Aluko, O.B. 2009. Effects of tillage methods on soybean growth and yield in a tropical sandy loam soil. International Agrophysics 23: 147-153.

Mahamood, J.; Abayomi, Y.A.; Aduloju, M.O. 2009. Comparative growth and grain yield responses of soybean genotypes to phosphorous fertilizer application. African Journal of Biotechnology 8: 1030-1036.

Moitra, R.; Ghosh, D.C.; Sarkar, S. 1996. Water use pattern and productivity of rainfed yellow sarson (Brassica rapa L. var glauca) in relation to tillage and mulching. Soil and Tillage Research 38: 153-160.

Norwood, C.A. 1999. Water use and yield of dryland row crops as affected by tillage. Agronomy Journal 91: 108-115.

Obalum, S.E.; Obi, M.E. 2010. Physical properties of a sandy loam Ultisol as affected by tillage-mulch management practices and cropping systems. Soil and Tillage Research 108: 30-36.

Obi, I.U. 2002. Statistical Methods of Detecting Differences between Means and Research Methodology Issues in Laboratory and Field Experiments 2ed. Snaap Press, Enugu, Nigeria.

Obi, M.E.; Nnabude, P.C. 1988. The effects of different management practices on the physical properties of sandy loam soil in southern Nigeria. Soil and Tillage Research 12: 81-90.

Odurukwe, S.O.; Aniebunwa, F.O; Iloka, A.W.; Udealor, A.; Ibedu, M.A. 1995. Indigenous Fallow and Multi-Purpose Tree and Shrub Species in the Farming Systems of South-East Zone of Nigeria: Report of a Diagnostic Survey. National NRCRI, Umudike, Nigeria.

Oluwasemire, K.O.; Stigter, C.J.; Owonubi, J.J.; Jagtap, S.S. 2002. Seasonal water use and water productivity of millet-based cropping systems in the Nigeria Sudan savanna near Kano. Agricultural Water Management 56: 207-227.
Onwualu, A.P.; Ahaneku, I.E. 2001. Conservation and conventional tillage effects on soil properties and soybean production. Agro-Science 2: 26-36.

Pederson, P.; Lauer, J.G. 2003. Corn and soybean response to rotation sequence, row spacing, and tillage system. Agronomy Journal 95: 965-971.

Rasiah, V.; Kohl, R.A. 1991. Water use by soybean in two soils with and without irrigation. Soil Technology 4: 159-165.

Rathore, A.L.; Pal, A.R.; Sahu, K.K. 1998. Tillage and mulching effects on water use, root growth, and yield of rainfed mustard and chickpea grown after lowland rice. Journal of the Science of Food and Agriculture 78: 149-161.

Rodrigues, J.G.L.; Gamero, C.A.; Fernandes, J.C.; Miras-Avalos, J.M. 2009. Effects of different soil tillage systems and coverages on soybean crop in the Botucatu Region in Brazil. Spanish Journal of Agricultural Research 7: 173-180.

Singer, J.W.; Logsdon, S.D.; Meek, D.W. 2008. Soybean growth and seed yield response to tillage and compost. Agronomy Journal 100: 1039-1046.

Srivastava, A.K.; Naidu, D.; Sastri, A.S.R.A.S.; Urkurkar, J.S.; Gupta, B.D. 1996. Effects of water stress on soybean productivity in Central India. Available at: http://drought.unl.edu/pubs/dnn/ arch2.pdf. [Accessed Dec. 5, 2008].

Stern, R.D.; Dennett, M.D.; Dale, I.C. 1982. Analysing daily rainfall measurement to give agronomically useful results. 1. Direct methods. Experimental Agriculture 18: 223-236.

Temperly, R.J.; Borges, R. 2006. Tillage and crop rotation impact on soybean grain yield and composition. Agronomy Journal 98: 999-1004.

Tessier, S.; Peru, M.; Dyck, F.B.; Zentner, R.P.; Campbell, C.A. 1990. Conservation tillage for spring wheat production in semiarid Saskatchewan. Soil and Tillage Research 18: 73-89.

Thiagalingam, K.; Dalgliesh, N.P.; Gould, N.S.; McCown, R.L.; Cogle, A.L.; Chapman, A.L. 1996. Comparison of no-till and conventional tillage in the development of sustainable farming systems in the semi-arid tropics. Australian Journal of Experimental Agriculture 36: 995-1002.

Tilander, Y.; Bonzi, M. 1997. Water and nutrient conservation through the use of agroforestry mulches, and sorghum yield response. Plant and Soil 197: 219-232.

Varvel, G.E. 1995. Precipitation use efficiency of soybean and grain sorghum in monoculture and rotation systems. Soil Science Society of America Journal 59: 527-531.

Wilhelm, W.W.; Wortmann, C.S. 2004. Tillage and rotation interactions for corn and soybean grain yield as affected by precipitation and air temperature. Agronomy Journal 96: 425432.

Willatt, S.T.; Olsson, K.A. 1982. Root distribution and water uptake by irrigated soybeans on a duplex soil. Australian Journal of Soil Research 20: 139-46.

Yusuf, R.I.; Siemens, J.C.; Bullock, D.G. 1999. Growth analysis of soybean under no-tillage and conventional tillage systems. Agronomy Journal 91: 928-933.

Zougmore, R.; Mando, A.; Stroosnijder, L. 2004. Effect of soil and water conservation and nutrient management on the soil-plant water balance in the semi-arid Burkina Faso. Agricultural Water Management 65: 103-120.

Received April 29, 2010

Accepted November 30, 2010 